\title{
Basic Magmatic Formations within the Eastern Part of the Bükk Mountains, North-East Hungary
}

\author{
Ádám Bartók ${ }^{1,2}$ \\ 1. MECSEKÉRC Zrt., H-7633 Pécs, Esztergár Lajos u. 19., Pécs, Hungary \\ 2. Faculty of Science and Technology, Department of Mineralogy and Geology, University of Debrecen, Debrecen H-4032, Hungary
}

Received: March 10, 2015 / Accepted: March 25, 2015 / Published: April 25, 2015.

\begin{abstract}
The macro- and microscopic results were that this body of basalt tectonically heavily loaded, strongly altered by clay minerals and characterized by hydro-metasomatic alteration. The geochemical analyzes revealed that the original magma could be a mantle origin of high iron and magnesium containing basalt (tholeiites, 10\%-15\%). As regards to the palaeogeographic environment, it can be said that due to the periodic sea flooding, it pushed into a lower area, covered with sediment where the surrounding areas were highlighted (bükkszentkereszt and bükkszentlászló tuffs).
\end{abstract}

Key words: Szinva metabasalt formation, Bükkian magmatism, upper szinva source region, metabasalt, tholeiitic magma, intracontinental volcanism.

\section{Introduction}

The background of this study comes from the researching group of the Department of Mineralogy and Geology, "Tardona-team" which has been prospecting the area of the Bükkium for fifteen years. It covers the strongly tectonized paleo-mesozoic basement and the hill ramp (Bükkhát) which is mainly built up of Oligocene and Miocene molassz basin sediments. Due to the micro tectonic measurements ( $>$ 20,000) it became apparent that within the platform carbonates of marine sediment, the basaltic rocks (basalt, andesite, quartz porphyry) are determinant of their morph tectonic environment and they were strongly contributed to the regional deformation caused by the direction of SW, SE and S compression, promoting the development of karstification in the breccia zones [1,2]. Therefore, their presence in many ways raises interesting questions:

- What is the paleo-facial genetic relationship between the embedding environment and the

Corresponding author: Ádám Bartók, M.Sc., research fields: planetary and earth sciences. E-mail: adam1515@freemail.hu. magmatic rocks?

- What kind of plate tectonic and volcanological processes can be reconstructed?

- How can we get a more accurate reconstruction of their ages and petro genetic?

- What levels of transformations were suffered in the simultaneous and post-magmatic processes during the structure evolution?

- Do these magmatic bodies-special regard to the basalt - contain exotic minerals, facies elements, genetic phenomena?

In this study, the basaltic rocks were primarily the subject of the study. These types of formations lie like a curve from Szarvaskő to the border of Miskolc, do not form a continuous chain of bodies. Their orientations fit into the morph tectonic direction of the Bükk Mountains which determines the whole direction of the Bükk. Of these, the easternmost edge member around the Szinva source (the formation was named after it) the materials were studied. The basalt bodies can be observed on the east and west side of the Szinva source up to approximately 200 meters (E-W orientation). The area has been examined with 
the size ratio of 1:1000 sufficient detail traversal on the spot. Both sides were performed by micro tectonical observations where the rock contact, appearance, development, and other structural lesions were also studied. On this basis, appropriate samples have been collected from the embedding environment and the typical lesions of the basalt body. These samples were processed in the laboratory of the Department of Mineralogy and Geology, Debrecen prepared for the macro- and microscopic, and geochemical analyzes. The macro- and microscopic results were that this body of basalt tectonically heavily loaded, strongly altered principally by clay minerals and characterized by hydro-metasomatic alteration. The geochemical analyzes revealed that the original magma could be a mantle origin of high iron and magnesium containing basalt (tholeiites, $10 \%-15 \%)$. Due to the periodic sea flooding, the area was pushed into a lower area and covered with sediment where the surrounding areas were highlighted (bükkszentkereszt and bükkszentlászló tuffs). Plan for further is that to examine the samples by CL-SEM (cathodoluminescence scanning electron microscopy) method and the clay minerals by an X-ray diffraction study which will support our conception and we shall get a more accurate and more precise picture of the evolution, development and erosion of the area.

\section{Applied Methods}

The eastern and western side of the east-western oriented basalt body which can be followed among the Szinva source up to approximately 200 meters was examined on the spot with the size ratio of 1:1,000.

The samples were processed and prepared for the macro-, microscopic and geochemical analyzes in the laboratory of the Department of Minerals and Geology, in Debrecen. Two polished rock slabs and thin sections from the embedding limestone and 43 pieces from the different appearance basalt body were made by cutting disk, polishing machine and different fineness silicon carbide emery. The thin sections have been investigated by a type of Nikon-Microphot SA polarizing researcher microscope and the photo documentations were taken by a type of Nikon FX 35DX. From the above mentioned samples those basalt variants have been chosen which were representing the different levels of transformation. Powder fineness grists have been made from four of them by a steelcylinder, a ball mill and an agate mortar.

These samples were squeezed into an aluminum sample pastilles under very high pressure and addition of wax binder on 1,000 degree Celsius and annealed for 30 minutes. The determination of $\mathrm{Al}, \mathrm{Si}, \mathrm{Ti}, \mathrm{K}, \mathrm{Ca}$ and $\mathrm{Fe}$ was made by an $\mathrm{X}$-ray fluorescence method (Rigaku 3063P wavelength dispersive spectrometer). Approximately $50 \mathrm{mg}$ annealed powder sample, measured by $0.1 \mathrm{mg}$ accuracy was digested with 2 molar concentrated $\mathrm{HCl}$ and 2 molar $\mathrm{HF}$ solution. After it, $100 \mathrm{ml}$ volumetric stock solutions have been made. $\mathrm{Mg}$ was determined by AAS (atomic absorption spectroscopy) and Na was determined by FES (flame emission spectrometry) from the stock solutions. Both elements were observed by Zeiss-Jena AAS-1 machine using air-acetyleneflame on the temperature of 2,200-2,300 degree Celsius. The moisture and structural water content of the samples have been determined from $10 \mathrm{mg}$ powder rock samples, measured by $0.1 \mathrm{mg}$ accuracy. Measured samples were left in porcelain crucible for 12 hours on the temperature of 105 degree Celsius and the moisture content have been calculated from the mass loss $\left(-\mathrm{H}_{2} \mathrm{O}\right)$. Dried samples were kept on the temperature of 1,000 degree Celsius for 30 minutes to determine the ignition loss. The ignition loss have been calculated after cooling, from the measured mass loss. The major element composition given in oxide form and calculated to dry matter have been used for the internationally approved nomenclature and petrographic evaluation method $[3,4]$.

\section{Research History, Preliminaries}


A lot of experts have been drawing attention to the research of the Bükk Mountains (North-East Hungary) over the course of more than 160 years. There are extremely large number of professional publications but there are few publications related to the magmatism of the Bükk Mountains (North-East Hungary). In this study a short overview is given of just those researchers' study whose are important for our point of view.

"Unclear stratification conditions, complete lack of definable fossils, also often dense forest cover are caused that the Bükk Mountains (North-East Hungary) is one of the most difficult and ungrateful recording areas and the decipherment of the stratification is a very difficult geological problem to solve." In 1866, Stache described the situation in his short study of the mapping operations. ZOLTÁN SCHRÉTER conducted mapping operations in the area of the Mountains between 1912 and 1917 with the size ratio of 1:25,000. While the age of the Paleozoic shales, its carbon age was obvious for him too until he changed the classification of the bright limestone from year to year. Based on the meanwhile gathered fossil materials he significantly changed the classification of the layers [5]. He placed the Eastern Bükk's vulcanite and within the Szinva Metabasalt Formation in the Paleozoic which forms the basis of this study. He concluded about the szarvasköi basic magmatic formations that it should be given a younger age than Middle-Triassic.

KÁLMÁN BALOGH radically changed in his normative study the description of the stratigraphic classification [6]. He recognized that the lillafüred section was overturned and due to this recognition he recorded a continuous Triassic sequence and regarded the Gömöri Karst and the Rudabányai Mountains' Triassic sequence as valid for the Bükk Mountains (North-East Hungary) too. When he did mapping around Hámor slightly changed this classification.

Serious debate has been going on for decades as regards the metabasalts around the Upper Szinva source that how this formation fits into its calcareous environment. This topic was regularly bypassed from the early research of the Bükk Mountains (North-East Hungary) because there was no meaningful explanation.

GÁBOR PANTÓ was the first who gave an advanced petrographic description about the magmatites which were investigated by him. He described primarily quartz porphyries and diabase tuffs within the surroundings magmatites [7]. There was an assumption for a long time that it was a result of an ocean floor vulcanism which is related to the western branch of the Vardar Zone-opened in the Upper Mid-Triassic (Dinári Ofiolite Belt) and there is a very strong genetic connection between them [8]. The metasomatic alteration of the formation and then mixing with carbonates was caused by partly contemporary contact with seawater and bottom sediments, partly Cretaceous-Miocen tectonical processes. This assumption could have been taken place when Bükk and Dinarids have been associated with large structural relationship which is based on stratigraphic facies. They were removed from each other due to the Late Mesozoic and Paleogene tectonical processes [9].

This cannot be clearly ruled out because secondary mineral associations and mineral assemblages in many places are in a very strong connection with this type of metamorphism. Another assumption was that it has been a result of an intraplate, within plate continental vulcanism. This also should not be unanimously ruled out because the flinty content and mainly the carbonate, lime-alkali content of the basalt confirms it. Geological mappings and geochemical researches (TEM, SEM) which was conducted by the Hungarian Geological Institute (MÁFI) in the second half of the 1970 have been questioned the pertinence of age of Southern Bükk shales and the structural model of the Bükk Mountains (North-East Hungary) but the first modification attempt is still unpublished. According to present standpoint, the Szinva Metabasalt Formation 
is a strongly deformed stratigraphic sequence which is composed of basalt lava and volcaniclastics with aleurolite, crinoidal limestone, radioralite lenses and intermediate settlements based on the current rock stratigraphic catalogue [10]. Previously it was part of the "óhutai diabáz" [11]. Partly it settles into the Hollóstető Formation. Its maximum thickness is 50 meters.

\section{Field Surveying}

Our main aim was to try to find any contact zone both on the eastern and western sides of the basalt body with the limestone. Firstly, the basalt body has been walked around along the driveway and has been selected the borderlines with 2 pieces of spreaders paint. Then 200-200 meters have been done upward on the two mentioned directions in order to determine approximately how many meters the surface outcrop should be continued. Thrust planes, striae and slicks have been found. It was documented. Photos have been taken, site plan has been made and samples have been collected on the spot (Fig. 1).

The measured structural stresses on the adjacent limestone outcrops and basalt body, the orientation of deformations and fractures were strongly correlated with each other which were suggesting that the basalt has suffered the same deformations as the embedding calcareous sequence. Similar observations have been examined on the Szentistvánhegyi Metaandezite Formation's environment along the road to Jávorkút. Primarily, compression effects were identified in this directions and due to these forces, the sequences were folded, folded fractional and foliated (regional metamorphism). The detected compression structural main directions have been chronologically vergenced to ENE, then to NW and finally to $\mathrm{N}$ in this region. Their multiple repetition can be assumed from the Early Cretaceous to present day. The Northerly could be the resultant of the previous two forces and these two deformation systems have been strongly overprinted by it, taking over its features.

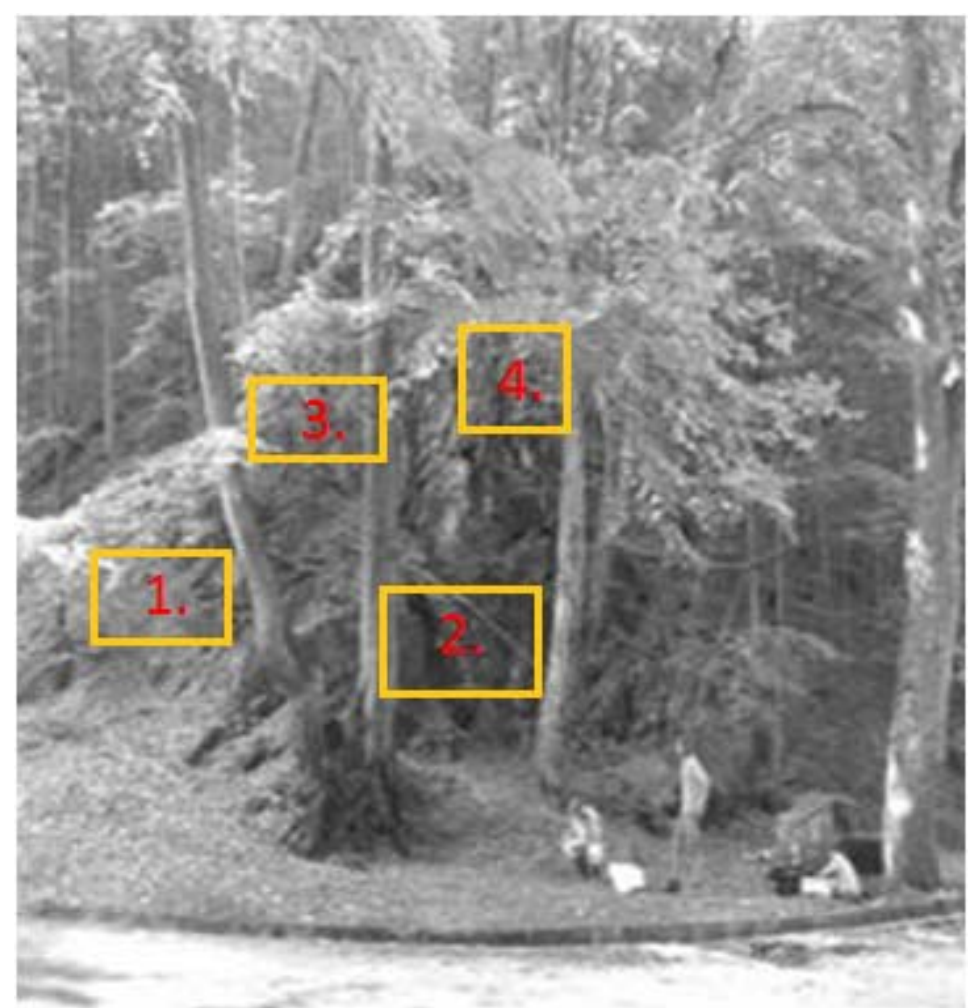

Fig. 1 The western location of field sampling, where each squares with the appropriate numbers show the different sampling points. 


\section{Petrographic Observations}

Altogether, we could say about the macroscopic samples that the basalt was hard, brittle, tectonically squeezed, compressed and there were some little faults observed under polarized light microscope. On the cutted, broken surfaces were medium, medium to light gray in color. The outer rims of the samples were covered by limonite, disaggregated and brown in color. There was visible on the polished surfaces that the fabric is rolled out and the micro faults were parallel with this direction. Smaller and larger, long drawn, thin and flat cavities can be found along the fabric directionality with complete or partial filling of carbonate. These parts of samples reacted violently with hydrochloric acid. At larger than 10-fold magnification traces of microporosite can be detected on the polished surfaces. Small whitish patches can be observed according to the directionality in the greenish color rocks. Probably it was crumpled with carbonates because it indicates violent reaction with acid.

It can be followed that an earlier fold has been overprinted by the schistose pressing in the region. For most of the thin sections were true that their color is pale greenish gray by held up to light and slightly banding can be observed according to the foliation. Examined under polarized light microscope the original rock could have been a strongly rolled out, disaggregated and altered basalt or basaltic andesite. There were traces of foliation and folding in its texture. The last foliation has given a unified directionality to most parts of the texture. This was the main foliation direction. Many micro faultsoccurred along this direction. More remains of the original rock can be recognized in some bands. There were disaggregated, compressed and altered in varying degree while the other parts of the rock showed chaotic image due to the remains of folding. Probably it was folded into several directions and the foliation was not unidirectional.
Minerals and its inclusion materials were orientated according to this foliation. The original texture appeared subofitic in the best preserved texture remains (a few mm patches within a band) which was turned into a direct phase in some places. Minerals of the original rock remains were primarily composed of plagioclases which were very rarely larger than the border of visibility to naked eye. Three generations can be distinguished according to the remains in the rock. The biggest was squatty and extended (first generation), the second generation was thin and slatted, the third generation was composed of needle crystals which presence was due to the abruptly, shocked cooling.

The plates of plagioclases were twined and their number was small. The mosaic and undulation extinction of the grains indicated that the rock was influenced by dynamo metamorphic effects. The majority of the crystals were broken, compressed, hipidiomorph and just some parts of them were idiomorph. It was possible that crystal germs which were embedded in the base material were also plagioclases but it was compressed and lubricated by structural movements so it was very difficult to identify them. The colored components cannot be identified. It can be assumed at some remains that they could have been pyroxenes. Opaque grains cannot be found in the matrix. They were destroyed by meta effects and alteration. It can be clearly seen that the base material was colored with limonite. The most distinctive ones will be presented from that samples which were documented by photos and these indicated the orientation of specific structural movements (Figs. 2-5).

\section{Geochemical Observations}

Our samples were strongly crumpled with the embedding limestone, therefore the laboratory investigations were great help for the determination of the major element composition, as shown in Table 1. 


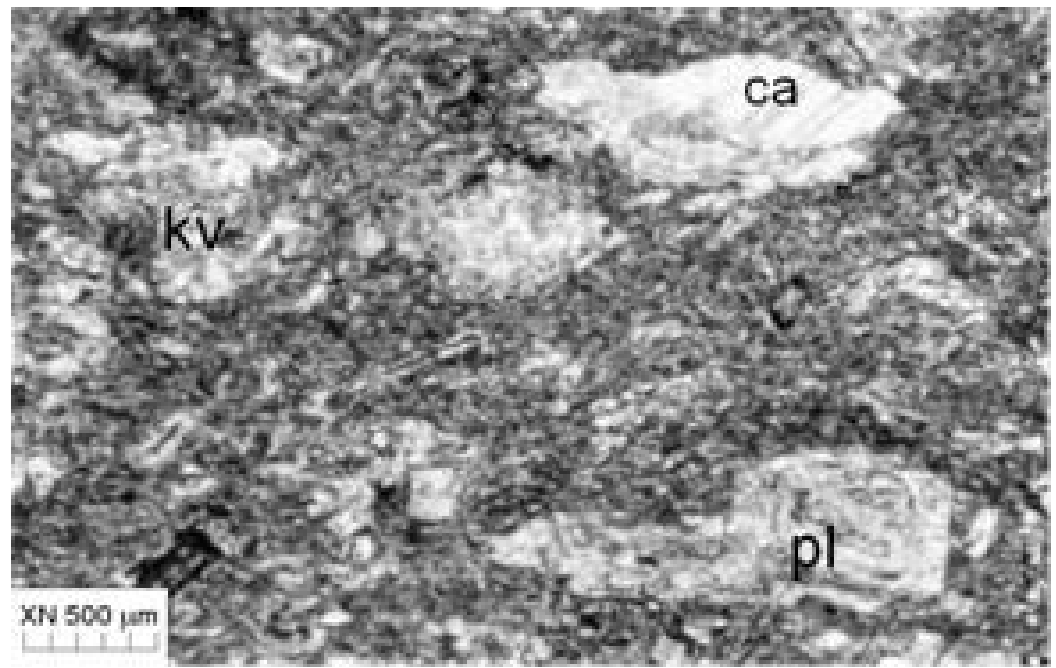

Fig. 2 Calcite and quartz oriented embedding can be seen in the relict fabric which appears directionally and undulating. There are many slatted, second and third generational, basic plagioclases in the fabric which show zoned extinction.

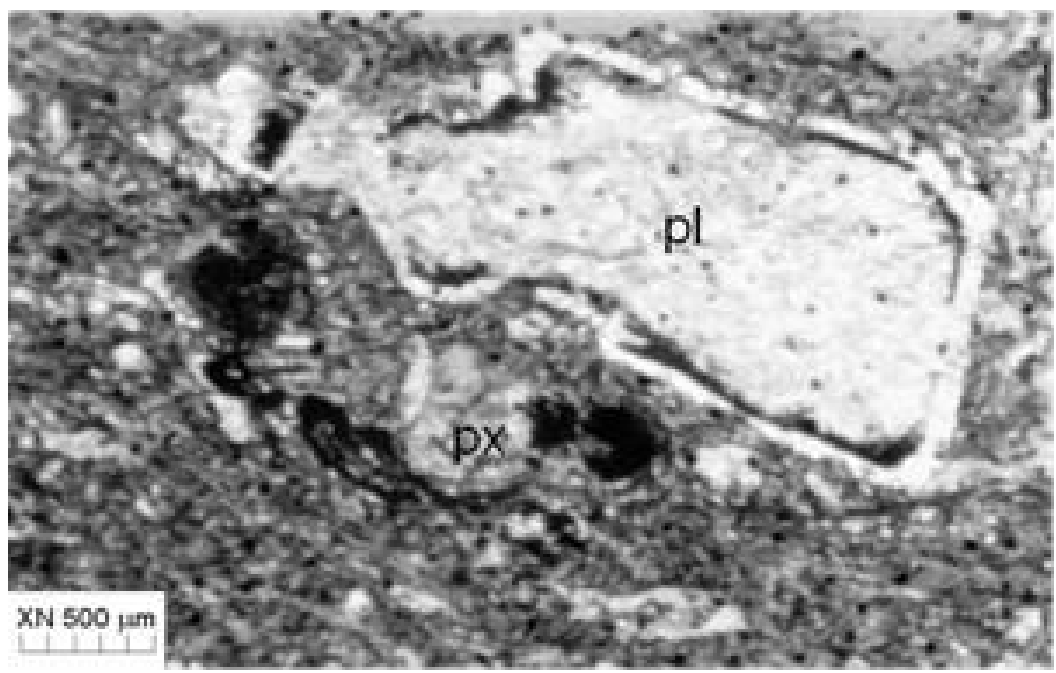

Fig. 3 First generational feldspar locates centrally, further growth rims can be clearly seen. Augite can be detected under it which is an important colorful rock component beside the hiperstene.

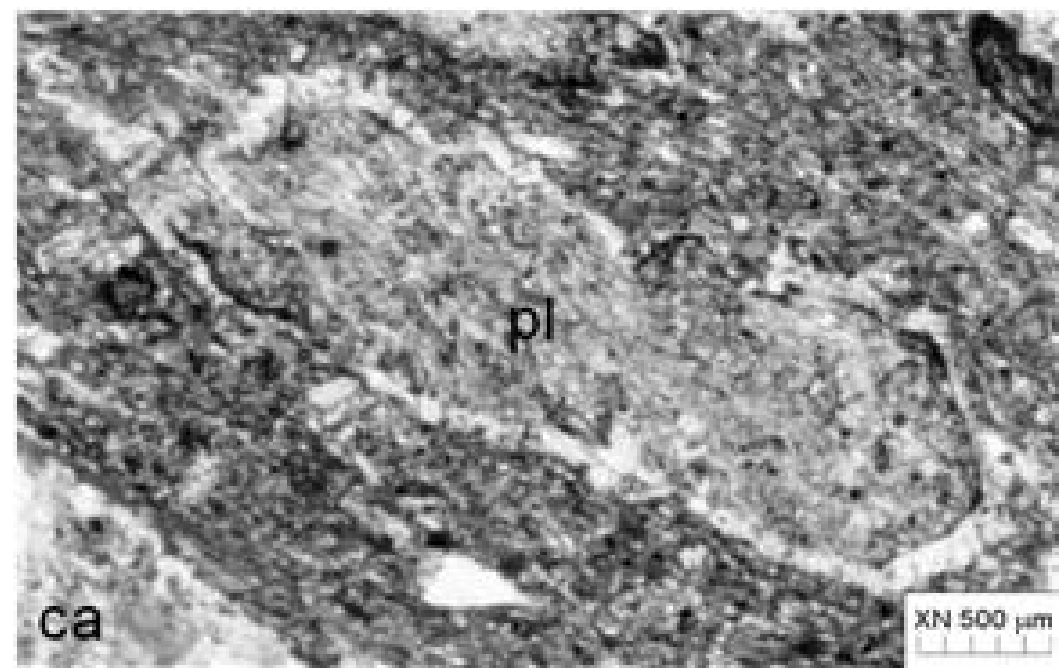

Fig. 4 Large-scale, deformed plagioclase, embedded in directed fabric. 


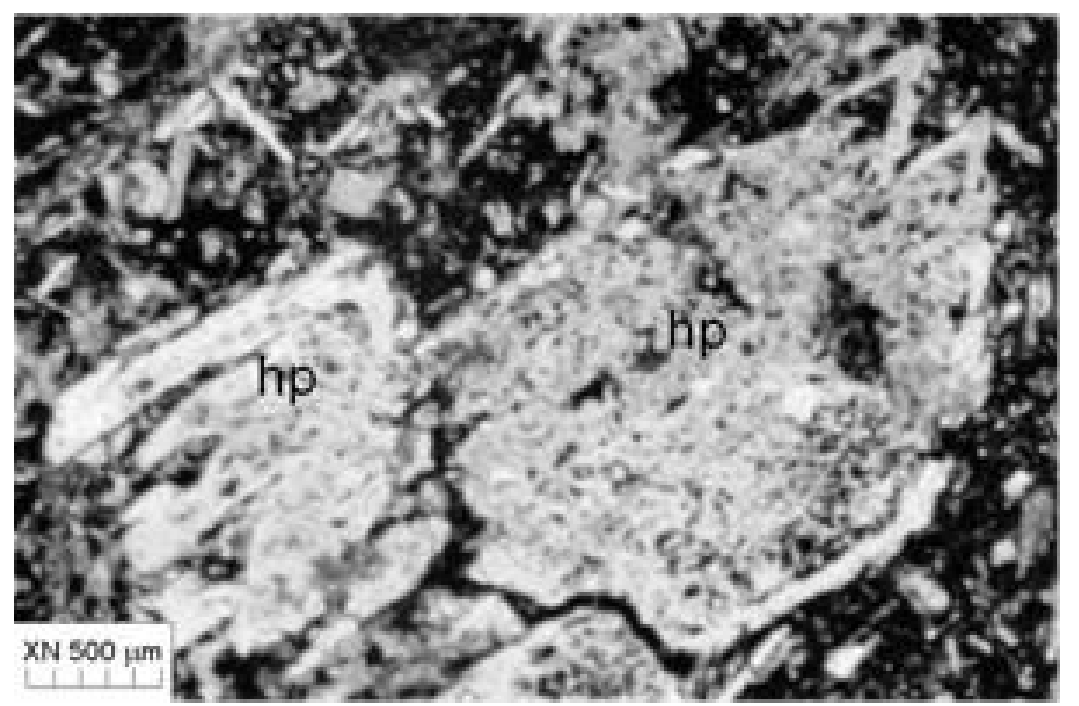

Fig. 5 Directed, subofitic fabric; a large-scale, first generational pyroxene can be identified in the center of field of view which is filled out by calcium derived from the alteration products.

Table 1 Element composition of the Szinva Metabasalt Formation calculated on the dry material.

\begin{tabular}{|c|c|c|c|c|c|c|c|c|c|c|c|}
\hline \multirow{2}{*}{ Sample No. } & \multirow{2}{*}{$\mathrm{SiO}_{2}$} & \multirow{2}{*}{$\mathrm{TiO}_{2}$} & \multirow{2}{*}{$\mathrm{Al}_{2} \mathrm{O}_{3}$} & \multirow{2}{*}{$\mathrm{Fe}_{2} \mathrm{O}_{3}$} & \multirow{2}{*}{$\mathrm{MnO}$} & \multirow{2}{*}{$\mathrm{MgO}$} & \multirow{2}{*}{$\mathrm{Na}_{2} \mathrm{O}$} & \multirow{2}{*}{$\mathrm{K}_{2} \mathrm{O}$} & \multirow{2}{*}{$\mathrm{P}_{2} \mathrm{O}_{5}$} & \multicolumn{2}{|r|}{ TAS } \\
\hline & & & & & & & & & & $\mathrm{SiO}_{2}$ & $\mathrm{Na}_{2} \mathrm{O}+\mathrm{K}_{2} \mathrm{O}$ \\
\hline BA-1 & 42.16 & 1.43 & 16.83 & 10.95 & 0.1 & 16.33 & 1.7 & 2.96 & 0.1 & 42.16 & 4.66 \\
\hline BA-2 & 38.31 & 1.17 & 14.74 & 9.19 & 0.11 & 13.11 & 2.12 & 2.35 & 0.19 & 38.31 & 4.47 \\
\hline BA-4 & 48.72 & 1.34 & 16.12 & 8.86 & 0.09 & 12.64 & 2.6 & 1.1 & 0.2 & 48.72 & 3.71 \\
\hline
\end{tabular}

Data have been plotted in the TAS diagram from the following table (Fig. 6) where three points can be observed in the province of basic and ultrabasic with low total alkali content $\left(<5 \% \mathrm{Na}_{2} \mathrm{O}+\mathrm{K}_{2} \mathrm{O}\right.$ content and $<\mathrm{Si}_{2} \mathrm{O} \%$ content; foidite, basalt and tefrite).

Finally, data have been put into the AFM plot too (Fig. 7) [4]. Here the points were appeared on the border of the tholeiitic and total alkali content which can be referred to the tectonics, metamorphism, somatic, kalimetasomatic and clay mineralization processes because the limestone and basalt rocks were strongly crumpled with each other. Our samples should be classified into the tholeiitic series according to the high $\mathrm{Mg}$ content.

\section{Conclusions}

Both phenomena could have been observed during the observations (including the intracontinental and ocean floor vulcanism or oceanic crust opening) in case of the samples from the field, the macro- and microscopic samples. Geochemical observations have been given the biggest assistance for us including the table of the distribution of major elements, TAS and AFM plot. The high Fe and Mg content were fully demonstrated that the original magma could have been a mantle origin, tholeiitic basalt. It can be said about the palaeogeography of the observed area that the adjacent parts could have been better highlighted relative to the area of the Szinva source than today's Bükkszentkereszt and Bükkszentlászló area (bükkszentkereszt and bükkszentlászló tuffs and scatter) which could have been developed in a drier environment (arid or semiarid) in that earth historical time period, due to their exposure. The up flowing and penetrating magma has been presumably pushed into shallow marine sediments to the area of Szinva. 


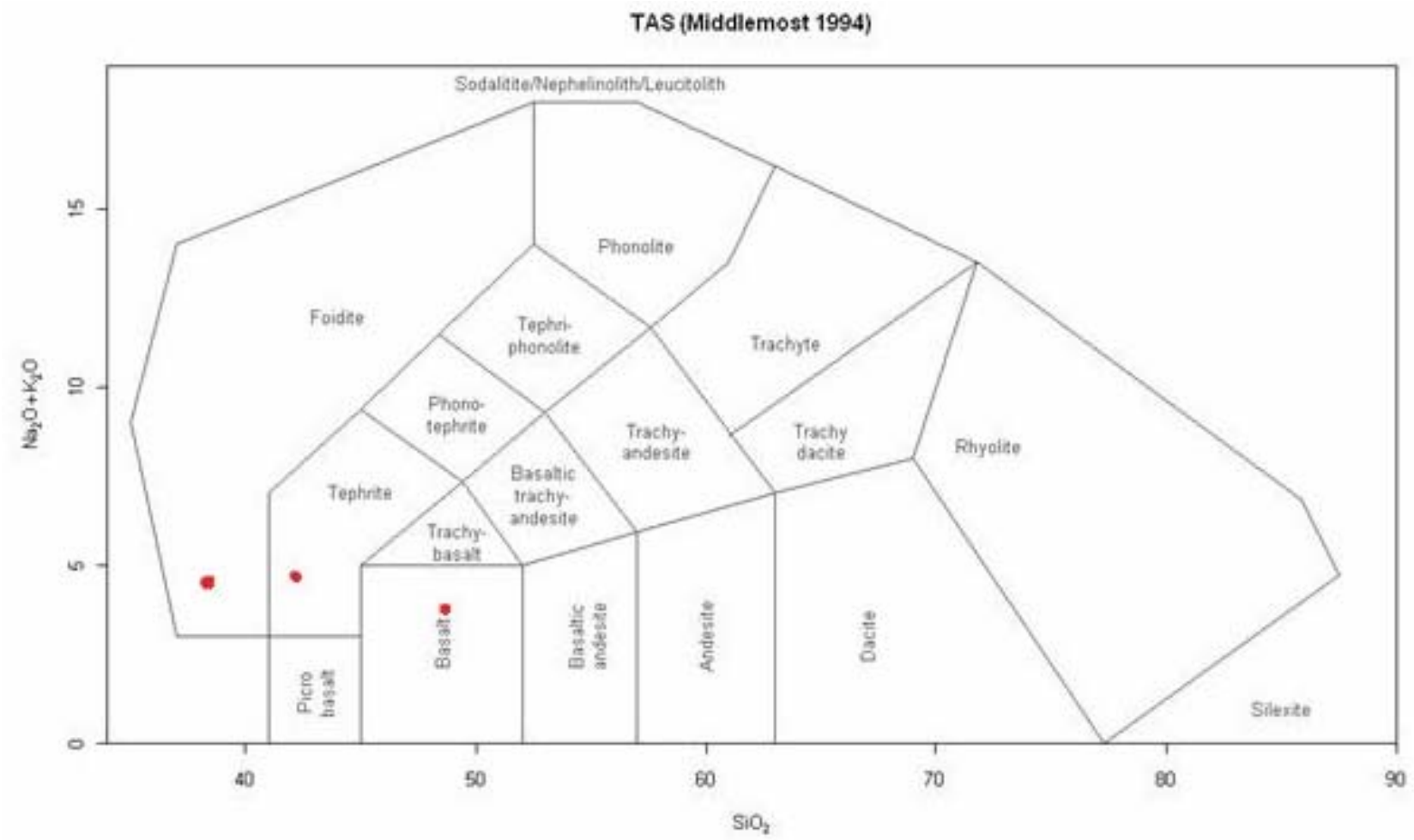

Fig. 6 Using TAS diagram at the Upper Szinva source.

\section{AFM plot (Irvine and Baragar 1971)}

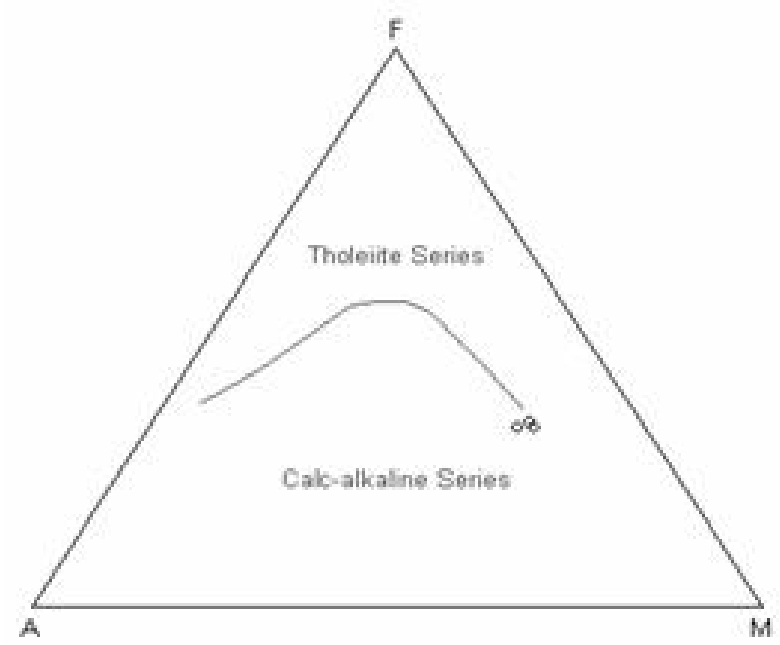

Fig. 7 Using AFM plot at the Upper Szinva source.

\section{Acknowledgements}

I owe a debt of gratitude to Dr. Miklós Kozák-associate professor of the Geology and Mineralogy of the University of Debrecen, Hungary from whom I had been inspiring and helping me in undertaking this study.

It is also my duty to record my thankfulness to McIntosh Richard William-assistant lecturer of the Geology and Mineralogy of the University of Debrecen, Hungary who always supported and encouraged me.

\section{References}

[1] Kozák, M., Püspöki, Z., and McIntosh, R. 2001. "Outline of the Development of Bükkium's Structure in the Light of Recent Regional Studies." Acta Geographica Ac Geologica Et Meteorologica Debrecina Tom. 35: 125-59.

[2] McIntosh, R. W., and Kozák, M. 2006. "The Experiences of Tectonic Recording in the Bükk Mountains." In Proceedings of the Mining, Metallurgy, Geology EMT Sepsiszentgyörgy, 262-67.

[3] Irvine, T. N., and Baragar, W. R. A. 1971. "A Guide to the Chemical Classification of the Common Volcanic Rocks." Canada Journal of Earth Sciences 8: 523-48.

[4] Le Maitre, R. W. 1989. A Classification of Igneous Rocks and Glossary Terms. Recommendations of the International Union of Geological Sciences Subcommission on the Systematics of Igneous Rocks. Trowbridge: Blackwell Scientific Publication. 
[5] Schréter, Z. 1935. "Triassic Formations of the Bükk Mountains (Über die Triasbildungen des Bükk-Gebirges)." Földtani Közlöny 65 (4-6): 90-105.

[6] Balogh, K. 1950. "The Triassic Stratigraphy of Northern Hungary.” Földtani Közlöny 80 (7-9): 231-37.

[7] Pantó, G. 1951. "The Geological Situation of the Eruptives between Diósgyör and Bükkszentkereszt (Geology of the Southern Igneous Belt in the Eastern Part of Bükk Mts.).” Földtani Közlöny 81 (4-6): 137-45.

[8] Kubovics, I., Szabó, Cs., Harangi, Sz., and Józsa, S. 1990. "Petrology and Petrochemistry of Mesozoic Magmatites Suites in Hungary and Adjacent Areas" Acta Geodaet.
Geophys. et Montanist. Hung. 25 (3-4): 345-71.

[9] Balla, Z. 1987. "Tectonics of the Bükkian (North Hungary) Mesozoic and Relations to the West Carphatians and Dinarids." Acta Geologica Hungarica 30: 257-87.

[10] Császár, G. 1997. Product of the Subcommissions of the Stratigraphic of Hungary. Budapest: H.G.I. (Hungarian Geological Institute).

[11] Pelikán, P. 1988. Bükk, Bükkszentkereszt, Lörinc Hill, Óhuta Diabase Formation, Hollóstetö Limestone Formation: Geological Basic Units of Hungary 97. Budapest: H.G.I. 